\title{
Travel Motivation and Domestic Tourist Satisfaction in Bali, Indonesia
}

\author{
Filda Rahmiati ${ }^{1^{*}}$, Norfaridatul Akmaliah Othman ${ }^{2}$, Vincent Bonavisi ${ }^{3}$ \\ 1,3 President University, Bekasi, Indonesia 17550 \\ ${ }^{2}$ Universiti Teknikal Malaysia Melaka, Melaka, Malaysia 76100
}

\begin{abstract}
A B S T RA C T
Bali has been selected as the best tourist destination in Indonesia, which have been popular worldwide. This research aimed to analyze the domestic tourist satisfaction in Bali based on Motivation factors. Previous studies supported that motivation could encourage and attract someone to do tourism activities and expecting satisfaction. This research used a quantitative research method to evaluate the motivation factors of Relaxation, Prestige, Cultural, and Accessibility on Tourist Satisfaction. Non-probability sampling with convenience sampling was used in this study. Questionnaires was distributed to 110 tourist tested with validity and reliability before data analysis. All the indicators are valid and reliable which further analyze motivation factors on tourist destination. Data analysis used in this research were multiple linear regression. The result affirmed that relaxation, cultural, and accessibility have significant on tourist satisfaction in Bali, hence, prestige has no significant on tourist satisfaction. Further, all motivation factors have simultaneously significant on tourist satisfaction in Bali with $76.3 \%$ of adjusted $R^{2}$.
\end{abstract}

C) 2018 IJBS, All rights reserved.

\section{ART I CLE INFO}

\section{Keywords:}

Motivation,

Relaxation,

Prestige,

Cultural,

Accessibility,

Satisfaction.
${ }^{*}$ Corresponding Author E-mail:

filda.rahmiati@president.ac.id

Copyright $@$ 2018Authors. This is an open access article distributed under the Creative Commons Attribution License, which permits unrestricted use, distribution, and reproduction in any medium, provided the original work is properly cited.

\section{INTRODUCTION}

Tourist arrival in global increased by $7 \%$ in year 2017 which is $4 \%$ or higher growth since 2010 as a strongest results (UNWTO, 2018). Tourism will continue constantly contribution to the economy of the country. It tends to occur in all countries in the world including Indonesia (Hermansyah \&
Waluya, 2012). Indonesia as one of the countries rely on tourism as a source of foreign exchange earnings, has various tourist destinations for tourists in the world (Wijaya, 2015). Foreign exchange earnings from the tourism sector in 2016 of US \$ 13.568 billion were second position after 
CPO of US \$ 15.965 billion. It has increased from US \$ 12.225 billion in 2015 (Chandra \& Damarjati, 2017).

Bali has been selected as the best tourist destination in Indonesia, which have been popular worldwide (Aminudin, 2013). Bali Province is one of province in Indonesia where the main source of income based on tourism as the beautiful natural and cultural scenery which interested by tourists. As an increasing number of tourists visiting Bali, it encourage the growth of supporting facilities for tourists such as hotels, accommodation, restaurants, etc (Purnama \& Yasa, 2013). Data in 2017 based on Bali Government of Tourism Office (2017), there are 2,251 restaurants, 4,290 accommodations consists of 231 stars hotels and 4,059 unstars hotels and various places of interest (natural tourism, spiritual tourism and also shopping tourism).

Bali has long been a favorite of tourist destination for sun and surf, but now its coastline disappears under the mountains of garbage. Plastic straws and food packs are strewn amongst the sunbathing tourists, while surfers are swayed behind the waves dodging rubbish that flows out of the river or carried by a swirling current (Welle, 2017). Further, in rainy season, Bali is flooded with plastic waste from the ocean. In addition to making the tourist attraction of Bali declining, tons of tons of plastic waste can endanger marine and human life (Utama \& Komalawati, 2015; Welle, 2017).

Traffic jam also becomes a problem that occurred in Bali as a form of the economic progress of people of Bali. This traffic jam occurs in urban areas and some places of tourism in Bali as well as the road to Kuta Beach which causes disruption of accessibility in Bali (Utama \& Komalawati, 2015). Tourists who visit a destination aim to relax get distracted by traffic jam (Hermansyah \& Waluya, 2012). As well as cultural issues, the influence of global culture is also become a problem in Bali because it influences the identity and character of people of Bali, many people of Bali have been influenced by global culture (Mukiroh \& Setiyorini, 2012). Based on several problems mentioned, this study tries to find out the satisfaction of tourist (as dependent variable) in Bali based on travel motivation factors (as independent variables).

\section{LITERATURE REVIEW}

Tourism sector in a destination is affected by travel motivation (Isa \& Ramli, 2014). Motivation of travel is also viewed as part of psychological and biological needs that encouraging and attracting someone to do tourism activities and expecting satisfaction (Chiu, Zeng, \& Cheng, 2016; Correia, Kozak, \& Ferradeira, 2013; Isa \& Ramli, 2014; Kanagaraj \& Bindu, 2013; Khuong \& Ha, 2014; Utama \& Komalawati, 2015). Eid \& El-Gohary (2015) proved that satisfaction is came from cognitive as well as emotional. This suggests that tourists will enjoy a traveling if their expectations match the post-travel experience otherwise tourists who feel their expectations are not in accordance with reality then they will feel dissatisfied (Chen \& Chen, 2010). According to Utama and Komalawati (2015), tourists will be able to obtain satisfaction from service that provided by the product of tourism if the service meets the quality of service and in accordance with expectations that expected by the tourists.

There are push and pull motivation factors (Chen, 2013; Lien, 2010; Mohammad \& Som, 2010; Wang, Luo, \& Tang, 2015). Push factor refers to intangible, intrinsic desires of tourist and it could be the individual tourist's desire to escape, rest and relaxation, health and fitness, adventure, prestige, and social (Isa \& Ramli, 2014). Further, push factor consists of escape motives (Hermansyah \& Waluya, 2012; Liên, 2010; Isa \& Ramli, 2014), relaxation (Isa \& Ramli, 2014; Mohammad \& Som, 2010; Hermansyah \& Waluya, 2012; Kanagaraj \& Bindu, 2013; Liên, 2010), prestige (Isa \& Ramli, 2014; Mohammad \& Som, 2010; Hermansyah \& Waluya, 2012; Kanagaraj \& Bindu, 2013; Liên, 2010), family and friend togetherness (Hermansyah \& Waluya, 2012; Liên, 2010), knowledge, health and fitness (Liên, 2010; Isa \& Ramli, 2014; Kanagaraj \& Bindu, 2013), adventure (Liên, 2010; Isa \& Ramli, 2014), and social (Liên, 2010); Isa \& Ramli, 2014). This study discussed two sub-variables of push factor that are relaxation and prestige, which most 
discussed by previous research.

Relaxation is about taking short walks, learning about the local nature and then not needing to worry about what to do as daily program should be available as well as organized trips, and other packages (Hermansyah \& Waluya, 2012). Stated by Pesonen et al. (2013) "relaxation is tourists experience to relax because they want to escape from the usual environment and rest when on holiday to get satisfaction". On the other hand, Prestige in the study of tourism is the desire of tourists to increase the social status and to visit a destination that would impress their friends and family (Mohammad \& Som, 2010).

Pull factor is defined as a force that can help to stimulate a product of tourism by attracting tourists to a specific destination (Mukiroh \& Setiyorini, 2012). Further, pull factor is external motivation to travel which based on the attractiveness of the destination (Isa \& Ramli, 2014). Pull factor consists of events and activities (Mohammad \& Som, 2010; Kanagaraj \& Bindu, 2013), accessibility (Kanagaraj \& Bindu, 2013; Mukiroh \& Setiyorini, 2012; Isa \& Ramli, 2014; Mohammad \& Som, 2010; Liên, 2010), cultural (Mukiroh \& Setiyorini, 2012; Isa \& Ramli, 2014; Mohammad \& Som, 2010; Kanagaraj \& Bindu, 2013; Liên, 2010), variety seeking (Liên, 2010; Isa \& Ramli, 2014; Kanagaraj \& Bindu, 2013), natural resources (Mohammad \& Som, 2010; Kanagaraj \& Bindu, 2013), heritage sites (Kanagaraj \& Bindu, 2013; Liên, 2010), and sightseeing variety (Kanagaraj \& Bindu, 2013; Liên, 2010). Thus, this study discussed two sub-variables of pull factor which are cultural and accessibility, which most discussed by previous research.

Cultural is the desire to acquire knowledge, such as music, art, dance, folklore, and religion (Mukiroh \& Setiyorini, 2012). While based on Mohammad \& Som (2010), cultural is the desire of tourists to seek satisfaction by increasing knowledge with culture, arts, and traditions in foreign destination. Mentioned by Kadir (2015), accessibility is defined as convenience of information and good transportation. Accessibility is about good facilities and infrastructure such as transportation, public telephones, and sidewalks for pedestrians which can affect tourist satisfaction (Mukiroh \& Setiyorini, 2012).

\section{RESEARCH METHOD}

The quantitative approaches are used in this study to find that relaxation, prestige, cultural, and accessibility can create tourist satisfaction in Bali. In this research, the researcher using primary data that obtained directly from the questionnaire that used for survey using five-point scale of Likert Scale. Do pretest using validity test and reliability test. When the questionnaire valid and reliable, the researcher spread the real test and collect them for data analysis. The researcher used Google Form to make the questionnaire. After that, the researcher distributed the questionnaire to respondents. The link of the questionnaire was distributed through social media like WhatsApp, LINE, etc.

The population of this study is tourists who ever been holiday to Bali and this research collected 110 returned questionnaires which will be used for data analysis. Data analysis used in this study is multiple linear regression to predict how the influence of independent variables to dependent variable partially as well as simultaneously significant. Lastly, this research will do coefficient of determination analysis (R2) to measure the strength of dependent variable explained by all independent variables.

\section{RESULT AND DISCUSSION}

\section{Respondent profiles}

Based on gender, out of 110 respondents' majority of respondents are males with 64 respondents followed by female of 46 respondents as seen on Table 1.

Table 1. Respondents Profile by Gender

\begin{tabular}{|c|c|c|}
\hline Gender & Number of Respondents & Percentage \\
\hline Male & 64 & 58.2 \\
\hline Female & 46 & 41.8 \\
\hline Total & 110 & 100 \\
\hline
\end{tabular}

In terms of experience, majority of respondents are repeated visitors with 63 respondents and firsttime visitors of 47 respondents as seen on Table 2 . 
Table 2. Respondents' experience visiting Bali

\begin{tabular}{|c|c|c|}
\hline Experience & $\begin{array}{c}\text { Number of } \\
\text { Respondents }\end{array}$ & Percentage \\
\hline First time visit & 47 & 42.7 \\
\hline Repeated visit & 63 & 57.3 \\
\hline Total & 110 & 100 \\
\hline
\end{tabular}

The length of stay of respondents divided into three categories: 1-3 days, 4-6 days, and more than 6 days. Majority of respondents' length of stay are 4-6 days, followed by 33 days of 33 respondents and more than 6 days of 14 respondents as seen on Table 3.

Table 3. Respondents' length of stay

\begin{tabular}{|l|c|c|}
\hline Length of stay & $\begin{array}{c}\text { Number of } \\
\text { Respondents }\end{array}$ & Percentage \\
\hline 1-3 days & 33 & 30 \\
\hline 4-6 days & 63 & 57.3 \\
\hline More than 6 days & 14 & 12.7 \\
\hline Total & 110 & 100 \\
\hline
\end{tabular}

\section{Pre-Test}

In this study, Pearson's Product Moment Coefficient Correlation used for test the validity of the questionnaire. By using significant level, $(\alpha)=5 \%(0.05)$ for two tailed and $n=40$ (researcher uses 40 respondents at the sample pre-test), the value of $r$ table is 0.312 , means that the $r$ value should be more than 0.312 to be valid as seen in Table 4. Another pretest is reliability test, Cronbach Alpha should be more than 0.6 used to measure the reliability as seen on Table 5 .

Table 4. Validity Result

\begin{tabular}{|l|c|c|c|}
\hline \multirow{4}{*}{ Variables } & Questions & $\begin{array}{c}\text { Pearson } \\
\text { Correlations } \\
\text { (r) }\end{array}$ & Variables \\
\hline \multirow{4}{*}{ Relaxation } & Re1 & 0.517 & Valid \\
\cline { 2 - 4 } & RE2 & 0.558 & Valid \\
\cline { 2 - 4 } & RE3 & 0.549 & Valid \\
\hline \multirow{4}{*}{ Prestige } & PR1 & 0.766 & Valid \\
\cline { 2 - 4 } & PR2 & 0.694 & Valid \\
\cline { 2 - 4 } & PR3 & 0.736 & Valid \\
\cline { 2 - 4 } & PR4 & 0.591 & Valid \\
\hline \multirow{3}{*}{ Cultural } & CU1 & 0.681 & Valid \\
\cline { 2 - 4 } & CU2 & 0.783 & Valid \\
\cline { 2 - 4 } & CU3 & 0.649 & Valid \\
\hline
\end{tabular}

\begin{tabular}{|l|c|c|c|}
\hline \multirow{4}{*}{ Accessibility } & AC1 & 0.708 & Valid \\
\cline { 2 - 4 } & AC2 & 0.595 & Valid \\
\cline { 2 - 4 } & AC3 & 0.689 & Valid \\
\hline \multirow{4}{*}{$\begin{array}{l}\text { Tourist } \\
\text { Satisfaction }\end{array}$} & SA1 & 0.764 & Valid \\
\cline { 2 - 4 } & SA2 & 0.519 & Valid \\
\cline { 2 - 4 } & SA3 & 0.446 & Valid \\
\cline { 2 - 4 } & Sa4 & 0.659 & Valid \\
\hline
\end{tabular}

Table 5. Reliability Result

\begin{tabular}{|l|c|c|l|}
\hline Variables & Items & $\begin{array}{c}\text { Cronbach's } \\
\text { Alpha }\end{array}$ & Category \\
\hline Relaxation & 3 & 0.718 & Reliable \\
\hline Prestige & 4 & 0.853 & Reliable \\
\hline Cultural & 3 & 0.839 & Reliable \\
\hline Accessibility & 3 & 0.812 & Reliable \\
\hline Tourist Satisfaction & 4 & 0.784 & Reliable \\
\hline
\end{tabular}

\section{Multiple Linear Regressions}

Below explain the Multiple Linear Regressions equation with details of significant influence partially as well as simultaneously. Lastly, coefficient of determination analysis (R2) to measure the strength of dependent variable explained by all independent variables as seen in Table 6.

Tourist Satisfaction $=0.455+0.494$ Relaxation 0.072 Prestige +0.205 Cultural +0.673 Accessibility .

Table 6. Multiple Linear Regressions Result

\begin{tabular}{|c|c|c|c|c|}
\hline \multicolumn{2}{|c|}{ Dependent variable } & \multicolumn{3}{|c|}{ Tourist Satisfaction } \\
\hline \multicolumn{2}{|c|}{ Independent variables } & \multicolumn{3}{|c|}{ Relaxation } \\
\hline & & \multicolumn{3}{|c|}{ Prestige } \\
\hline & & \multicolumn{3}{|c|}{ Cultural } \\
\hline & & \multicolumn{3}{|c|}{ Accessibility } \\
\hline Multiple R & & \multicolumn{3}{|c|}{0.879} \\
\hline $\mathrm{R} 2$ & & \multicolumn{3}{|c|}{0.772} \\
\hline Adjusted R2 & & \multicolumn{3}{|c|}{0.763} \\
\hline Std Error & & \multicolumn{3}{|c|}{1.68089} \\
\hline $\mathrm{F}$ & & \multicolumn{2}{|c|}{88.769} & Sig. 0.000 \\
\hline $\mathrm{N}$ & & \multicolumn{2}{|c|}{110} & \\
\hline Model & $b$ & Beta & $\mathbf{t}$ & Sig. \\
\hline Constant & 0.455 & & 0.588 & 0.558 \\
\hline Relaxation & 0.494 & 0.340 & 4.440 & 0.000 \\
\hline Prestige & -0.072 & -0.075 & -1.078 & 0.283 \\
\hline Cultural & 0.205 & 0.167 & 2.206 & 0.030 \\
\hline Accessibility & 0.673 & 0.521 & 6.841 & 0.000 \\
\hline
\end{tabular}


Based on the data above, this research concludes that:

1. Relaxation has b value 0.494 and the value for the significant is 0.000 less than 0.05 . It can conclude that relaxation has positive and significant on tourist satisfaction.

2. Prestige has b value -0.072 and the value for the significant is 0.283 greater than 0.05 . It can conclude that prestige does not have positive and insignificant on tourist satisfaction.

3. Cultural has $b$ value 0.205 and the value for the significant is 0.030 less than 0.05 . It can conclude that cultural has positive significant on tourist satisfaction.

4. Accessibility has $b$ value 0.673 the value for the significant is 0.000 , less than 0.05 . It can conclude that accessibility has positive significant on tourist satisfaction.

5. Simultaneously, all independent variables (Relaxation, Prestige, Cultural, and Accessibility) have significant value of 0.000 . It can conclude that all independent variables have positive and significant on tourist satisfaction with adjusted R2 of 76.3\% tourist satisfaction influence by all independent variables.

\section{CONCLUSIONS AND IMPLICATIONS}

In this final study, the researcher draws the conclusion and recommendation developed from specifically the multiple regression analysis, about motivation factors on tourist satisfaction. Based on result above, three motivation factors of Relaxation, Cultural and Accessibility have positive and significant on tourist satisfaction. Whereas, Prestige has negative and insignificant on tourist satisfaction. Here, researchers see that tourist visit to Bali not for prestige purposes as majority of them are repeated visitor. In overall, all motivation factors have positive and simultaneously significant on tourist satisfaction.

Based on significant value, relaxation and accessibility have 0.000 significant value. It shows that tourist visit to Bali because they enjoy Bali as for relaxation and because of easiness of its accessibility. Bali has international airport which cater most of international flights to make easy for every tourist to visit Bali.

As for recommendations, government of Bali needs to protecting the historical sites and maintaining the infrastructure that already exists and also improve the quality. So, the tourists can feel more satisfied.

\section{REFERENCES}

Bali Government of Tourism Office. (2017). Statistics of Bali. Retrieved from http://www.disparda. baliprov.go.id/en/Statistics2

Chen, C. F., \& Chen, F. S. (2010). Experience quality, perceived value, satisfaction and behavioral intentions for heritage tourists. Tourism Management, 31(1), 29-35. https://doi.org/10.1016/ j.tourman.2009.02.008

Chen , N. (2013). Luxury shopping as a Factor in Destination Choice : Vienna , a case study. Modul University.

Chiu, W., Zeng, S., \& Cheng, P. S.-T. (2016). The influence of destination image and tourist satisfaction on tourist loyalty: a case study of Chinese tourists in Korea. International Journal of Culture, Tourism and Hospitality Research, 10(2), 223-234.

Correia, A., Kozak, M., \& Ferradeira, J. (2013). From tourist motivations to tourist satisfaction. International Journal of Culture, Tourism and Hospi-tality Research , 7(4), 411-424. 
Eid, R., \& El-Gohary, H. (2015). The role of Islamic religiosity on the relationship between perceived value and tourist satisfaction. Tourism Management, 46, 477-488.

Hermansyah, D., \& Waluya, B. (2012). Analisis Faktor-Faktor Pendorong Motivasi Wisatawan Nusantara Terhadap Keputusan Berkunjung ke Kebun Raya Bogor (Survei Pada Wisatawan Nusantara yang Berkunjung ke Kebun Raya Bogor). Tourism and Hospitality Essentials Journal, 2(1), 245-268.

Isa, S. M., \& Ramli, L. (2014). Factors influencing tourist visitation in marine tourism: lessons learned from FRI Aquarium Penang, Malaysia. International Journal of Culture, Tourism and Hospitality Research, 8(1), 103-117.

Kadir, A. (2015). Laporan Akhir Kajian Pengem- bangan Wisata Syariah. Laporan Akhir Kajian Pengembangan Wisata Syariah.

Kanagaraj, C., \& Bindu, T. (2013). An Analysis of Push and Pull Travel Motivations of Domestic Tourists to Kerala. International Journal of Management \& Business Studies (IJMBS), 3(2).

Khuong, M. N., \& Ha, T. T. (2014). The Influences of Push and Pull Factors on the International Leisure's Return Intention to Ho Chi Minh City. Vietnam - A mediation Analysis of Destination Satisfaction. International Journal of Trade, Economics and Finance, 5(6).

Lien, P. T. K. (2010). Tourist Motivation and Activities A Case Study of Nha Trang, Vietnam. The Norwegian College of Fishery Science, University of Tromso, Norway \& Nha Trang University, Vietnam. University of Tromso, Norway \& Nha Trang University, Vietnam.

Liên, P.T.K. (2010). Tourist Motivation and Activities ACase Study of Nha Trang,Vietnam.

Mohammad, B. A. M. A.-H., \& Som, A. P. M. (2010). An Analysis of Push and Pull Travel Motivations of Foreign Tourists to Jordan. International Journal of Business and Management, 5(12).

Mukiroh, \& Setiyorini, H. D. (2012). Pengaruh Faktor-Faktor Penarik Kepariwisataan Wisatawan Asal Malaysia Terhadap Keputusan Berkunjung Ke Kota Pekanbaru (Survei Pada Wisatawan Asal Malaysia yang Berkunjung ke Kota Pekanbaru). Tourism and Hospitality Essentials (THE) Journal, 2(1), 269-290.

Pesonen, J., Komppula, R., Kronenberg, C., \& Peters, M. (2011). Understanding the relationship between push and pull motivations in rural tourism. Tourism Review, 66(3), 32-49.

Purnama, I. A. M. S., \& Yasa, I. N. M. (2013). Faktor-Faktor yang Mempengaruhi Keputusan Wisatawan Domestik Berbelanja di Pasar Oleh-Oleh Modern (Studi Kasus di Kota Denpasar). E-Jurnal Ekonomi Pembangunan Universitas Udayana, 2(5), 244-253.

Utama, I. G. B. ., \& Komalawati. (2015). Hubungan Motivasi Perjalanan Dan Kepuasan Wisatawan Mancanegara Lanjut Usia Berwisata Di Bali (Relationships Travel Motivation and Tourism Satisfaction of Senior Tourist Visiting Bali).Jurnal Kepariwisataan, 15(2).

Wang, T., Luo, Y., \& Tang, L. R. (2015). The investigation of consumer motivations to patronize boutique hotels using push-pull theory: a case study in Xiamen, China. International Journal of Tourism Cities, 1(4), 317-328.

Wijaya, K. (2015). Masa Depan Pariwisata Bali ( Perspektif Permasalahan Dan Solisinya ). Jurnal Riset Dan Ekonomi Manajemen, 15(1), 118-135. 